\title{
An Outline and New Aspects of the Regional Stratigraphy of Mongolia
}

\section{Dorj Dorjnamjaa}

Institute of Paleontology and Geology, Mongolian Academy of Sciences, Ulaanbaatar, Mongolia

Email:ddorj2001@yahoo.com

How to cite this paper: Dorjnamjaa, D. (2017) An Outline and New Aspects of the Regional Stratigraphy of Mongolia. Open Journal of Geology, 7, 1579-1589. https://doi.org/10.4236/ojg.2017.711106

Received: September 26, 2017 Accepted: November 3, 2017

Published: November 6, 2017

Copyright $\odot 2017$ by author and Scientific Research Publishing Inc. This work is licensed under the Creative Commons Attribution International License (CC BY 4.0).

http://creativecommons.org/licenses/by/4.0/

\begin{abstract}
This paper concerns deals with the Mongolian regional stratigraphic classification of sedimentary, sedimentary-volcanogenic sediments, and metamorphic complex spread over the territory of Mongolia according to the new International Chronostratigraphic Chart [1]. The regional stratigraphy of Precambrian-Cenozoic rocks of the Mongolian territory was studied by Dorjnamjaa et al. [2]. So, this paper provides for the stratigraphy and correlation of key sections through the Archean-Proterozoic-Mesozoic-Cenozoic of various areas of Mongolia. In this paper, the author introduces the most important results indicating the key reference sections for the first time and put into a broad regional context. The characterization and geologic mapping of lithological units provided an essential basis for the lithostratigraphy, biostratigraphy and chemostratigraphy. Especially key biostratigraphic aspects are the phenomenon of faunal succession. The basic lithostratigraphic unit is the formations and groups which have been successful mapped. At present in Mongolia for Precambrian period (systems and series) 30 formations and groups, for Paleozoic-about 250 formations and groups, for Mesozoic-102 formations and groups, for Cenozoic - 27 formations, members, and beds are distinguished. The auxiliary stratigraphic units are members, beds which should be mapped depending on great extent of detailed study. In the regional stratigraphical classification, there are two primary kinds of stratotypes [3]: a) unit stratotypes, which serve as the standard of definition for a stratigraphic unit, and b) boundary stratotypes, which serve as the standard of definition for a stratigraphic boundary. These aspects, in particular gradational boundaryas far as possible were examined for example for Archean-Paleoproterozoic (by geochronologic data), Ediacaran-Early Cambrian (by soft-bodied fossils, trace fossils and small shelly fossils), Ordovician-Silurian (by beyrichiidostracodes), Devonian-Carboniferous (by conodonds), Paleocene-Eocene (by mammals), Oligocene-Miocene (by small rodents) systems and series.
\end{abstract}




\section{Keywords}

Lithostratigraphy, Biostratigraphy, Paleontology, Classification, Correlation, Formation, Member, Bed, Reference Section, Organic Fossil, Fauna, Flora

\section{Introduction}

The present paper is the first distillation of the recent data on stratigraphic differentiation and correlation of Mongolia. In this paper, we have attempted to work out the original regional stratigraphic chart and give away more extensive explanation for stratigraphic division of the different aged and facial rocks widespread over the territory of Mongolia. The Mongolian republic is situated in the central part of the Asiatic continent. Geologic studies in different parts of Mongolian territory began in the middle of the $20^{\text {th }}$ century, but regular and extensive examination started in the seventies - eighties simultaneously with stratigraphic analyses of the all-aged deposits within the sedimentary basins. The Joint Russian-Mongolian Scientific Research Geological and Paleontological Expeditions played a main role in the study of the region. These studies commenced more than 50 years ago and are still in progress now partly. For common conception the author introduces the short comment concerning the regional tectono-stratigraphic unit's description of the Mongolian territory. According to Dorjnamjaa et al. [2] [4] [5] the Central Asian Foldbelt encompasses various Precambrian to Phanerozoic structures lying between the Chinese and Siberian cratons. The foldbelt consists of Baikalian (Early Paleozoic), Caledonian, Variscan, Late Variscan to Early Kimmerian, and Early Mesozoic structures. They compose mosaic of Fold Mountains and linear nappe-foldbelts [4], whose age generally declines from the Siberian to the Chinese Craton. The three main following folded regions are allocated in the territory of Mongolia [2]: Eastsayan-Mongolaltay, Central Mongolian and South Mongolian. Within these folded regions were apparent two structural stages. The lower one being the folded basement and the upper one the sedimentary cover. Within the mosaic areas, the Tuva-Mongolian and Central Mongolian massifs or smaller blocks have been recognized. These massifs and blocks consist of Middle-Late Archean and Early Proterozoic basement of high-grade metamorphic rocks (3.1 - 1.6 Ga) covered by the protoplatform Mesoproterozoic to Neoproterozoic rocks (732 $777 \mathrm{Ma}$ ) and the lower Neoproterozoic rift-related volcanics. Neoproterozoic to Cambrian sediments were identified according to paleontologic data [2] [6]. They compose a number of lithostratigraphic units: a) essentially volcanic dominated by basaltic volcanics and cherty-jasper rocks (ophiolitic formation); b) spilites and keratophyres associated with cherty carbonates; c) and esite-basalts and and esites with occasional reef limestones; d) cherty, clastic-carbonate phosphorite-bearing (shelfy facies within the Khubsugul and Zavkhanmarine basins). In Mongolian Altay, in the Khovd zone, Gornoaltay group is uncon- 
formably overlapped by several lithological formations. They are: tuffaceousclastic (Upper Ordovician), cherty-clastic graptolitic (Lower Silurian) and basalt-andesite with reef limestones (Silurian). South Mongolian folded belt comprises a number of narrow blocks differing in constituent associations. The following zones are recognized: Edrengiin, Trans-Altay, South Gobi including Gobialtay. The sequence of the Edrengiin zone largely consists of Middle Paleozoic (including Lower Carboniferous) sediments with abundant volcanic rocks. In the north of the zone they are composed of a thick succession of oligomictic sandstones $\left(\mathrm{O}_{3}-\mathrm{S}_{2}\right)$, greenstone-altered basalts and and esite-basalts associated with jasper (S-D), greywacke, flysch $\left(D_{1-3}\right)$. In the south of the zone, the base of the drilled part of the sequence is composed of dacites, rhyolites and their tuffs $\left(D_{2}\right)$, and limes tones with colonial Tabulata $\left(D_{2}\right)$. As a whole the Trans-Altay zone during the $S-\mathrm{D}_{1}, \mathrm{D}_{2}-\mathrm{C}_{1}$ stage is understood as a Lower to Middle Paleozoic structure with oceanic crust. The sequence in the SouthGobi zone is completed with acid tuffs, tuffites and tuff siliciliths (S-D). Besides the Southern Mongolian folded belt, a number of peculiar intermountain trough were formed within the northern folded area of the country. These are classified as superimposed (secondary), clastic troughs [4] [5]. The superimposed depressions are very characteristic of Central Mongolian and Mongol Altay folded regions. Here, the flyschlike sandy-slaty ( $\mathrm{D}$ in the Deluno-Yustyd and $\mathrm{D}-\mathrm{C}$, also $\mathrm{T}$ in the KhangayKhentii depressions) terrigenous sediments have been good mapped, their lithostratigraphy has been studied in detail and their age is based on faunal determination. Since the end of the Late Paleozoic the entire territory of the country has entered the continental stage of development. The main events during the Mesozoic were related to the evolution of Mongol-Okhotsk belt. In Mongolia this belt is characterized by extensive development of continental igneous rocks and practical absence of marine facies. Early Triassic clastic sediments with marine fauna occur only in the Jargalantiintrough in North-East Mongolia. In Mesozoic and Cenozoic time an intraplate rifting took place mainly in eastern and southern Mongolia with block-faulting movements, accompanied by significant intrusive activity. All the Upper Mesozoic superimposed depressions have been filled with continental molasses and intramountainclastic sediments containing zeolite, coal and oil-bearing sediments. Especially the Cretaceous terrigenousrocks in South Gobi contain abundance of terrestrial vertebrate (dinosaur, mammal, turtle, lizard, crocodile, fish) and invertebrate (ostracodes, oyster, conchostrac, pelecypod, mollusk, insert).

Stratigraphy is a branch of geology concerned with the study of rock layers (strata) and layering (stratification). It is primarily used in the study of sedimentary and layered volcanic rocks. As everybody knows that stratigraphy has two related subfields: lithologic stratigraphy or lithostratigraphy, and biologic stratigraphy or biostratigraphy [3]. Compositional, continuous variations, also lateral and vertical variations in beds of the orogenic and terrigenous sediments often reflects environmental and geobiofacies changes of deposition [2]. These 
variations were observed by us in Mesozoic continental sediments particularly. Biostratigraphy or paleontologic stratigraphy is based on fossil evidence in the rock layers. Strata from widespread locations containing the same fossil fauna and flora are said to be correlate able in time. All these facts and criteries were used for differentiation and correlation of the heterogeneous and various age rocks in Mongolia sufficiently successful. The paleomagnetic studies were conducted by Evans et al. [7] in Zavkhan basin for lower Cambrian Bayangol formation and by Russian geologists in western Mongolia for Cenozoic Khyargasnuur formation [8] [9]. The Bayangol formation, primarily siliciclastic with calcareous interbeds, contains small shelly fossils that are thought to correlate with Nemakit-Daldynian to earliest Tommotianbiozones in Siberia [10]. This method works by collecting oriented samples at measured intervals throughout a section. The samples were analyzed to determine their detrital remanence magnetism (DRM). Oriented paleomagnetic core samples were collected in the field: mudstones, compact limestones, siltstones, and very fine-grained sandstones are the preferred lithologies because the magnetic grains are finer and more likely to orient with the ambient field during deposition. Results of the individual samples were analyzed by removing the natural remanencemagnetization (NRM) Chemostratigraphic studies were carried out by us in Zavkhan basin for Ediacaran Tsagaanolom and lower Cambrian Bayangol formations [2] [10] [11] [12]. Using evidence from Brasier et al. [10] on carbon and strontium isotope stratigraphy, they argue that both diamictites of the Maikhanuul formation in Zavkhan basin are likely to be equivalent to the Sturtian glaciation of Australia (>710 $\mathrm{Ma}$ ) and the Rapitan of western North Amenal data obtained by the large authors, concerning stratigraphic and paleonrica. It should be emphasized that this article combines numerous, mostly origitological studies of Mongolia reflected in more than 300 bibliography and accumulated during more than 70 years of various geologic survey and thematic research done together with Soviet-Mongolian Geologic and Paleontological Expeditions of former USSR and Mongolian academies of sciences.

\section{The Regional Stratigraphic Differentiation and Main Paleontological Substantiation}

The Mongolian region is key in the geosystem of geological structures of Central Asia. Evidence of regional stratigraphy is presented in age sequence that corresponds to the major chronostratigraphic, lithostratigraphic and biostratigraphic classifications and correlations of the different regions' evolution: I-Precambrian-Cambrian, II-Ordovician, III-Silurian, IV-Devonian, VCarboniferous, VI-Permian, VII-Triassic, VIII-Jurassic, IX-Cretaceous, XPaleogene, XI-Neogene and XII-Quaternary. All these subdivitions are strictly corresponding to the International Chronostratigraphic Chart [1] and Mongolian Lithostratigraphic Code [13]. Record of the regional stratigraphic chart and subdivisions are enlarged outlined in form of the major lithostratigraphic unit, 
as regional horizons, also main local lithologic meta complexes, groups, formations, members and other stratum. For identification and description of the formations and other units were selected more representative reference stratigraphic sections confirmed by paleontological data at the same time lithological and other indirect database.

Mongolia is one of the Asiatic countries where paleontology is studied in detail. At the same time the abundance and diversity of paleontological fossils in different occurrences drew the attention of both amateurs and professional geologists. Although there was lack of laboratory of absolute age data resulted from verified lab analysis, the Archean crystal complex was divided into $\mathrm{Me}$ so-Archean and Neo-Archean [6] [14] [15]. The late Precambrian stage (1.6 $0.54 \mathrm{Ga})$ involved quartzite-carbonate, effusive-carbonate and schist-quartzite units [2] [6] [14] [15]. In Mongolian Precambrian glacial marine deposits (EdiacaranMaikhanuul formation) were discovered by us in Zavkhan region of western Mongolia in 1990s [16]; they discordantly overlie the volcanic rocks of Zavkhan formation (732 - $777 \mathrm{Ma})$ and are conformably over layed by the limestones of the Tsagaanolom formation (<632 $\pm 14 \mathrm{Ma})$. Upper Proterozoic and Early Cambrian faunal (corneosiliceous polyactinal sponge, ichnofossils, softbodied fauna, medusa, various SSF, archaeocyathids, trilobites) and floral (stromatolites, microphytolites assemblages, microfossils, calcareous algae) fossils, Burgess Shale biota and cyanobacterial mats are presented in taxonomic succession. Especially, the discovery of cyanobacterial microfossils in the Ediacaran and Early Cambrian phosphorites was a very important event. It led to the interpretation of the origin of bedded phosphorites which had been considered as biogenic genesis [2] [17] [18]. Lately geologic exploration and mappings, also some thematic joint research projects are intensified and conducted by Mongolian and international scientists make Phanerozoic stratigraphic classification become more detailed and precise. Especially, research on microfossils such as Conodont and Radiolaria allows the Ordovician, Silurian, Devonian and Carboniferous sediments to be categorized into stages and lithological formations. Moreover, Mesozoic sediments were possibly classified into stages and formations on the basis of rich in vertebrates alike terrestrial floral fossils. The Cenozoic deposits including Oligocene and Miocene are classified as stages and into biostratigraphic units, but its lower contact with Eocene is still not clear. It should be mentioned that within the Altay Inner Gobi the lower Eocene horizon, as Bumban is recognized and the exact age of Shandgol horizon of the Lake's Valley is identified as Oligocene. This can be characterized as the criterion unit and provides possibility to be correlated to Cenozoic biostratigraphy of Europe and the USA.

The most ancient fossils were found as afore-mentioned in the Paleoproterozoic, Mesoproterozoic and Neoproterozoic strata-bound sedimentary rocks. The fossil fauna and flora are known in all strata of the geological succession from the Neoproterozoic, Cambrian and Ordovician to Neogene and Quaternary inclusive. In particular large exposures with Mesozoic and Cenozoic fossil rem- 
nants are located in the South Mongolian Gobi. So from the Ediacaran-lower Cambrian strata were discovered and described abundant paleontological diversity: cyanobionta, acritarchs, ichnofossils, soft-bodied fossils, SSF, chioliti, sponge, archaeocyatha, trilobites, brachiopods, radiolaria, molluscs, blue-green algae [2] [3] [14] [17] [19] [20] [21] [22] [23] bout 470 species of Bryozoans were revealed from 13 Ordovician localities [1], 32 Silurian 1., 90 Devonian 1., 48 Caroniferous 1., and 31 Permian 1. Also 65 species in 30 genera of heliolitids, rugose, tabulate Corals, Brachiopods, Crinoids are well-known from Ordovician, Silurian [24], Devonian, Carboniferous and Permian strata, as well as large number of Foraminifera (C-P), Graptolites (O-S), Conodonts (S-P), Trilobites (O, D-C), Gastropods (O, D-P), Stromatoporoids (O-D), Molluscs (S-P) and Ostracodes (O-S, D-P, MZ) at the same time Carboniferous, Upper PermianTriassicammonoidea [25] [26]. According to R. Barsboldand Kh. Tsogtbaatar [21] [27] [28] [29] from Mesozoic and Cenozoic deposits were well studied vertebrate and invertebrate faunal groups (e.g. Late Cretaceous gigantic carnivorous Tarbosaurs, an herbivorous Saurolophs, Sauropods, an enigmatic Deinocheirus, Ankylosaurs, Hadrosaur Barsboldia, Paleogene and Neogenemammalia (Dinocerata, Pantodonta, Lagomorphs), turtles, labyrinthodontia, ingenii, ostracodes, phillopods (conchostraca), molluscs, crocodiles, fishes, lizards, aves, insecta and so on). Particularly Late Paleozoic, Mesozoic and Cenozoic strata represent abundant fossil material of fresh-water chlorophytes and subaerial plants, also sporophytes [20] [21] [30].

We shall now take a more detailed look at the faunal radiations and extinctions during the Precambrian and Phanerozoic. The earliest fossil, that is widely accepted as a eukaryote is Grypania from a $2.1 \mathrm{Ga}$ banded iron formation in Michigan. The oldest protistan fossils are $\sim 1.9$ - 1.8 Ma acritarchs from China and Mongolia (Khangiltsagmeta complex) that may be interpreted as the eukaryotic or eubacterial, and acritarchs of probable eukaryotic origin are abundant in banded iron quartzite. Stromatolites are unequivocal evidence of the Earth's earlies benthos. There are several examples of 2.9 - 2.7 Gastromatolites in Zimbabwe, Canada (these reach $3 \mathrm{~m}$ in height and diameter), also Proterozoic stromatolites and microphitolites are known in Russia, China and Mongolia. Ancient (e.g. Precambrian) stromatolites thrived in Khubsugul and Zavkhan open shelf environments and occur in dolomites and limestones. These organisms are layered stratiform, conical or columnar, biogenic sedimentary structures that are built by trapping and binding and/or precipitation of sediment. Many soft-bodied animals have been found in Neoproterozoic rocks on several continents, providing evidence of early Metazoan life that existed before the appearance of hard parts. The topicality of these late Precambrian metazoans is very characteristic for Ediacaran in South Australia and Mongolia [2] [6]. The assemblage contains at least 26 species in 18 genera and 4 or more phyla, and includes many species that are known today such as jellyfish, sea anemones, the sea-wasp, worms, sponges, sea pens, and so on [31]. As everybody knows [2] [6] [12] [21] [31], 
that the Ediacaran fauna has a worldwide distribution with important localities in Russia (White Sea and N. Siberia), Canada (Newfoundland), Namibia, England (Charnwood), and Mongolia (Zavkhan area). The Neoproterozoic-Cambrian radiation comprised three main episodes or stages [6] [14] [18] [31]: 1) preEdiacaran-unicellularprocaryotes and eucaryotes. 2) Ediacaran fauna, phosphatic SSF and many shallow-water trace fossils. 3) Lower Cambrian calcareous SSF with the first archeocyathans, trilobites, brachiopods, echinoderms, molluscs and deeper and shallow-water trace fossils. The Ordovician was a major period of diversification-the brachiopods, graptolites, bryozoans, nautiloids and ostracodes expanded considerably, corals and stromatoporoids became worldwide. A broad shallow-water epicratonic sea covered much of Europe, North America, Siberia, Mongolia and the Yangtze platform in China and there were therefore no barriers to the migration of shelf faunas, which by the Silurian had a cosmopolitan character. In Devonian the reef complexes became progressively attenuated, resulting in the virtual extinction of the reef corals and stromatoporoids, trilobites, graptolited declined, surviving only until the end of the Carboniferous. The Devonian period is characterized by the appearance of fish, vascular plants, amphibians, winged insects and terrestrial vertebrates. Major transgressions in the Carboniferous led to the widespread deposition of shallow-water limestones with diversified corals and crinoids, giant cockroaches and graptolites. Amphibians flourished and gave rise to the reptiles and forests of trees such Lepidodendron and Sigillaria reached $30 \mathrm{~m}$ in height. In the Permian marine invertebrates were especially affected; trilobites, blastoids, fusulinid foraminifera, eurypterids, rugose corals, cephalopods, sponges, brachiopods, echinoderms, and many families of molluscs, all became extinct. Plant life was not seriously affected but vertebrates were. Between the Permian and the Triassic some $75 \%$ of amphibian and over $80 \%$ of reptile families disappeared. In the Triassic faunas were largely cosmopolitian and only a few major provinces can be differentiated. At this time the belemnoids, osreas, complex sutured ammonoids and echinoderms became important. Amongst the reptiles dinosaurs evolved on the land, plesiosaurs and ichthyosaurs in the sea and gliding pterosaurs in the air. Mammalia evolved from the the rapsid reptiles in the late Triassic. Land floras flourished with important palm like cycads, horsetails, conifers, ferns, cycad fern and ginkos (ginkgo). During the Jurassic those faunas that survived from the Paleozoic or were established in the Triassic continued to diversify. Ammonoids and foraminifera flourished, as did corals and sponges in carbonate reefs on shallow shelves. The frog (an amphibian), coccolith ophorida (planktonic plants), angiosperms (flowering plants) and the first bird (Archaeopteryx, with feathers developed from reptile scales) appeared. In the Cretaceous seas the planktonic globigerinas, coccoliths and diatoms became so abundant and calcareous sponges, jellyfish, corals, bryozoans, pelecypodmolluscs, cephalopods, echinoids and crinoids are strongly flourished. Reptiles retained a cosmopolitan character throughout the Mesozoic because, in spite of the fact that continents were drift- 
ing, there was sufficient connection between blocks to allow the dinosaurs and their contemporaries to wander for and wide. About it the Mongolian Cretaceous dinosaurs are being a clear example [29] [32]. At the end of the Cretaceous, $66 \mathrm{Ma}$ ago, about $70 \%$ of all living species became extinct, including the ammonites, belemnites, some plants, bryozoa, bivalve molluscs, echinoids and planktonic foraminifera, and most of the terrestrial, marine and flying reptiles (e.g. dinosaurs, ichthyosaurs and pterosaurs), of the reptiles only the crocodiles, snakes, turtles and lizards survived into the Tertiary [2] [31]. By the Eocene, primates, elephants, rhinoceroses, pigs, porpoises, whales and bats, as well as most orders of modern birds and many families of plants, had all appeared. The evolution of the vertebrates (e.g. fish, amphibians, reptiles and mammals) throughout the late Mesozoic and Cenozoic was strongly affected by the paleogeography and paleoclimatic conditions of the continents. Particularly Gondwanaland was more or less isolated from Laurasia in the late Mesozoic and this separation facilitated the development of two fairly distinct faunas. Many foraminifera such as the globigerinids and mammals evolved rapidly becoming abundant during the Tertiary. Gastropods, pelecypods and reef corals were the predominant invertebrates. Conditions for origin and following development of modern fauna and flora were appeared in the Late Neogene. Hominids began to evolve at about $4 \mathrm{Ma}$ with the first bipedal ape-men or anthropoid apes and finaly gave rise to our owen species Homo sapiens. Although throughout the report all the aforenamed faunal and floral fossils were revealed from the Mongolian Paleozoic and Mesozoic-Cenozoic sediments for the time being insufficiently but we have great hope in the further biostratigraphic and paleontological study undoubtedly.

\section{Quaternary Terrestrial Fauna}

Mongolia is one of the most ancient center of origin and subaerial fauna in our planet [33]. Owing to the remoteness from the civilized world and uninhabited vast territories there were preserved many large animals which were disappeared in other regions of the world. Ancient endemics and fauna relicts are characteristic. Thus the animal world of Mongolia is rich and diverse: about 630 kinds of vertebral animals, including 130 kinds of mammals, more than 400 kinds of birds. There are about 30 kinds of amphibians and reptiles, more 60 kinds of fishes. Here one can meet such rare and protected kinds of animals as: khulan (wild donkey), takhi (the Perzhevalsky horse), gobi bear or mazaalai, wild two-humped camel, mountain ram, snow leopard, saiga, bustard-beauty or jack, griffon, owl, pelican and swan, in rivers one can meet salmon species (tul or Salmotaimen, zeveg or lenok, kharius), sig (lake white-fish), sturgeon (khilem) and so on.

The main factors, such as global warming, glaciations, geodynamic development and changes in continental area, sea-level, seawater salinity, and supply of nutrients to the oceans together with extraterrestrial causes (impacts by earth- 
crossing asteroids and comets) were influenced on the distribution, diversity and extinction of past life of the fossil fauna and flora.

\section{Conclusions}

1) In light of new chronostratigraphycal views, we have analyzed the regional stratigraphycal interpretations and chart of Mongolia. It is suggested that numerous different lithostratigraphycal complexes are distinguished and identified as follows: for Precambrian period 5 regional horizons, 2 meta complexes, more 30 groups, formations, for Paleozoic-29 regional horizons, about 250 groups, formations, beds, for Mesozoic-11 regional horizons, 102 groups, formations, beds, and for Cenozoic-11 regional horizons, 27 formations and beds. However to notice that on the present research level the distinguished regional horizons have some failings with respect to vertical time interval of the horizons or interval between horizon's boundary, internal classification, also their age basis.

2) Based on the above lithostratigraphycal and paleontological data, we have determined some inter-systems and inter-series boundary. It is very sensitive and principal issue for stratigraphic science on the whole. The present in western Mongolia (southern part of Zavkhan basin, Khasagt Khairkhan mountain), the Precambrian and Cambrian boundary is established more reliable to carry out an intercontinental correlation. This year the International paleontologist's group from Sweden (Dr. C. B. Skovsted), Mongolia (Prof. D. Dorjnanjaa, B. Enkhbaatar, G. Altanshagai), United Kingdom (Dr. T. P. Topper), China (Prof. G. X. Li), Australia (Dr. M. J. Betts), and Japan (Prof. Yoichi Ezaki) should have studied in more detail the Ediacaran-lower Cambrian boundary and SSF in good known Bayangol, Salanygol, Tsagaangol and Taishirstratotype sections within the north Khasagt Khaikhan mountain.

3) Using the other sedimentological, palynological, and paleomagnetic studies, the Cenozoic, especially as Quaternary stratigraphy of the Mongolian territory and its relation to global change will be detailed in the near future.

\section{Acknowledgements}

We are indebted to Russian academician D. M. Voinkov, paleontologists A. L. Ragozina, E. A. Serezhnikova, Director of the Institute of Paleontology and Geology, MAS, Dr. Kh. Tsogtbaatar and academician R. Barsbold and Dr. J. Byamba for their valuable recommendation. We should also like to express our thanks to paleontologists, Dr. Yo. Khand and G. Sersmaa for their careful reading of the proofs and many helpful suggestions.

\section{References}

[1] International Chronostratigraphic Chart, International Commission on Stratigraphy (2017). www.stratigraphy.org

[2] Dorjnamjaa, D., Bat-Ireedui, Y., Ichinnorov, N., Enkhbaatar, B. and Altanshagai, G. (2017) Regional Stratigraphy of Mongolia (in Mongolian with English Abstract). Ulaanbaatar, 267. 
[3] Stratigraphical Classification. http://www.jstor.org/stable/43419070

[4] Dorjnamjaa, D., Badarch, G. and Orolmaa, D. (1994) The Geodynamic Evolution of the Mobile Fold Belts of the Territory of Mongolia. Proceedings of the 29th International Geological Congress, Part B, 71-84.

[5] Dorjnamjaa, D., Kovalenko, V.I., Byamba, J. and Voinkov, D.M. (2002) An Issue on Correlation and Development of the Central Asian Geodynamics and Metallogeny (in Mongolian). Proceedings of the Primary Character of Development of the Mongolian XXI Century, Ulaanbaatar, 85-102.

[6] Dorjnamjaa, D., Bat-Ireedui, Y., Enkhbaatar, B. and Altanshagai, G. (2016) Precambrian, Cambrian Geology and Paleontology (in Mongolian with English Abstract). Ulaanbaatar, 183.

[7] Evans, D.A., Zhuravlev, A.Y., Budney, C.J. and Kirschvink, J.L. (1996) Paleomagnetism of the Bayangol Formation, Western Mongolia. Geological Magazine, 133, 487-496. https://doi.org/10.1017/S0016756800007615

[8] Devyatkin, E.V. (1981) Cenozoic of Inner Asia (Stratigraphy, Geochronology, Correlation). Nauka, Moscow, 196. (In Russian)

[9] Devyatkin, E.V., Malaeva, E.M., et al. (1989) The Late Cenozoic of Mongolia. Nauka, Moscow, 156. (In Russian)

[10] Brasier, M.D., Shields, G., Kuleshov, V.N. and Zhegallo, E.A. (1996) Integrated Chemo-and Biostratigraphic Calibration of Early Animal Evolution: NeoproterozoicEarly Cambrian of Southwest Mongolia. Geological Magazine, 133, 445-485. https://doi.org/10.1017/S0016756800007603

[11] Graham, A.S., Stille, P., Martin, D.B., Nicu-Viorel, A. and Dorjnamjaa, D. (2002) On the Origin of High ${ }^{13} \mathrm{C}$ in the Neoproterozoic: ${ }^{13} \mathrm{C}$ carb.,${ }^{13} \mathrm{C}$ org. and Ce/Ce Data from Western Mongolia. Earth and Planetary Science Letters, No. 4, 49.

[12] The Neoproterozoic-Cambrian Succession in Mongolia (1996) Great Britain. Cambridge University Press, Geological Magazine, Vol. 133, No. 4, 143.

[13] Mongolian Lithostratigraphic Code (in Mongolian) (2016).

[14] Dorjnamjaa, D., Voinkov, D.M., Enkhbaatar, B. and Altanshagai, G. (2016) A New Look at the Precambrian and Cambrian Event Chronostratigraphic Correlation of Mongolia. Journal of Paleontology, 50, 1306-1313.

[15] Byamba, J. (2012) Geology and Mineral Resources of Mongolia. Volume I, Stratigraphy. Ulaanbaatar, 5.

[16] Dorjnamjaa, D. and Bat-Ireedui, Ya. (1991) The Precambrian of Mongolia (in Mongolian with English Abstract). Ulaanbaatar, 182.

[17] Dorjnamjaa, D. (2016) Neoproterozoic-Cambrian Biostratigraphy of the Ancient Phosphate Basins of Mongolia and the Influence of Bacterial Communities on Phosphorite Accumulation: A Review. International Journal of Agriculture Innovation and Research, 5, 372-384.

[18] Dorjnamjaa, D. and Altanshagai, G. (2015) Concerning the Original Viewpoint of Biogeological Accumulation of the Old Bedded Phosphorites in the Khubsugul and Zavkhan Basins of Mongolia. Open Journal of Geology, 5, 666-673.

[19] Dorjnamjaa, D., Enkhbaatar, B. and Altanshagai, G. (2014) Precambrian and Cambrian Regional Stratigraphy of Mongolia. In: Rocha, R., et al., Eds., STRATI 2013: First International Conference on Stratigraphy at the Cutting Edge of Stratigraphy, Springer IPS, 391-395. https://doi.org/10.1007/978-3-319-04364-7_76

[20] Ariunchimeg, Y. (2016) Paleozoic Bryozoans of Mongolia. Paleontological Journal, 50, 1348-1362. (In Russian) https://doi.org/10.1134/S0031030116120030 
[21] Byamba, J. and Barsbold, R. (2012) Geology and Mineral Resources of Mongolia. Volume II, Paleontology. Ulaanbaatar, 529.

[22] Ragozina, A.L., Dorjnamjaa, D., Serejnikova, E.A., et al. (2016) Prasinophyte Green Algae Tasmanites and Problematic Fossils in the Upper Vendian Biota of the Zavkhan Basin, Western Mongolia. Paleontological Journal, 50, 1314-1320. https://doi.org/10.1134/S0031030116120157

[23] Serezhnikova, E.A., Ragozina, A.L., Dorjnamjaa, D. and Zaitseva, L.V. (2014) Fossil Microbial Communities in Neoproterozoic Interglacial Rocks, Maikhanuul Formation, Zavkhan Basin, Western Mongolia. Precambrian Research, 245, 66-79.

[24] Minjin, C., Sersmaa, G., Ariunchimeg, Y., et al. (2001) The Guide Book: Mongolian Ordovician and Silurian Stratigraphy. Abstract Vol. for the Joint Field Meeting of the IGCP 410 and 421 in Mongolia/UNESCO, Inter. Geol. Correlation Program. 127.

[25] Khand, Y., Badamgarav, D., Barsbold, R. and Ariunchimeg, Y. (2000) Cretaceous Sedimentary Depositional Setting, Paleontology: A Review of Current Studies of Mongolia. Cretaceous Environments of Asia, 17, 49-79.

[26] Khand, Y., Munkhtsetseg, J. and Badamgarav, D. (2016) On the Stratigraphy of the Reference Section of the Upper Mesozoic Deposits of Undur-Bogd in Southern Mongolia. Paleontological Journal, 50, 1418-1420. https://doi.org/10.1134/S0031030116120091

[27] Barsbold, R. (1972) Biostratigraphy and the Freshwater Molluscs of Upper Cretaceous in Govi Part ofCretaceous, Mongolia. M.: Nauka, 85. (In Russian)

[28] Tsogtbaatar, K. (2008) Distribution Map of Mongolian Dinosaurs. Ulaanbaatar, 1-4.

[29] Berkey, C.P. and Morris, F.K. (1927) Geology of Mongolia. Vol. 38, 11.

[30] Gereltsetseg, L. (2016) A New Charophyte Species from the Upper Oligocene of Western Mongolia (Shine Us Locality). Journal of Paleontology, 50, 1470-1472. https://doi.org/10.1134/S003103011612008X

[31] Windley, B.F. (1995) The Evolving Continents. New York, 526.

[32] Tsogtbaatar, K. and Barsbold, R. (2015) Amazing Dinosaurs from Mongolia. Ulaanbaatar, 116. (In Mongolian)

[33] Marinov, N.A. and Florensov, A.N. (1979) Quaternary Map of Mongolia. Moscow. 